\title{
Two cases of scleroma in Iran
}

\author{
K. AlaVi, E. KOHOUT, AND W. DUTZ \\ From the Ear, Nose and Throat Department and the Department of Clinical Pathology and Pathology of \\ Pahlavi University, Shiraz, Iran
}

SYNOPSIS The distribution of rhinoscleroma in Asia is reviewed and two cases from Iran are added a region in which the disease seems not to have been previously reported. The pathogenesis of the disease is reviewed.

The clinical appearance of scleroma is usually characteristic and the disease is easy to diagnose (Fig. 1). von Frisch described the causative organism in 1882. Studies with fluorescent and immunofluorescent methods confirmed the exclusive role of $B$. rhinoscleromatis in the specific pathological picture (Hoffman, Correa, and Luian, 1963). Koch's postulates were, however, not completely fulfilled until recently (Hoffman, 1968). Although rabbits and mice could be infected experimentally, the lesions produced were not specific and self curative. Only $40 \%$ of a given litter showed abscess formation at the injection site after 15 to 20 days. The lesions disappeared spontaneously after 30 to 90 days. Multiple animal passage increased the virulence of the bacillus only slightly.

Recent experiments demonstrated that continuous and repeated injection of bacilli at the same site produces a granulation tissue indistinguishable from the characteristic lesion in the human nose (Hoffman, 1968). Equally good results can be achieved by a single injection of bacilli together with sterile mucus, which in some way prohibits phagocytosis of the organism and leads to specific pathological alterations.

These findings explain the low infectivity in the human subject and the restriction of the disease to the upper respiratory tract. Infection is favoured by close association with a diseased person for very long periods. Bacillus rhinoscleromatis has been isolated from the nasal mucosa of apparently healthy individuals. In all these cases a member of the family or some other close associate was infected. Manifest scleroma followed very frequently. Whole tribal groups and large families suffered infection (Oomen and Kirschner 1938; Aldoin, 1957). The disease affects the rural poor and 'unwashed' (Aldoin, 1957). Risk for both sexes is equal, although due

Received for publication 26 August 1970. to socioeconomic factors the incidence from differentw countries shows moderate variations. Only $5 \%$ of all cases occur amongst children: the majority are found in people between 15 and 35 years of age, which is a reflection on the short life expectancy in the countries frequently affected.

\section{Geographical Distribution}

The disease occurs under all climatic conditions. It has been described from Siberia, southern Switzerland, to the high Andes. Most cases are froma moderate climatic zones and the tropics. Wahi and市 Misra (1964) describe a scleroma belt on the Eurasian continent, extending from Yugoslavia, Bulgaria, and Rumania, on the northern and southern coast of the Black Sea to the Caucasus and the Central Asiatic Soviet Republics, from there to India and the Indonesian archipelago. No cases had been recorded from Iran and Afghanistan, which waso attributed to the high altitude of large parts of: these countries (Wahi and Misra, 1964).

The main European focus is Galicia (Poland and Russia). A high incidence of scleroma is reported 9 from Egypt, spreading throughout Africa. Most of $D$ the Central and South American cases are from Guatemala (Quevedo, 1949). Australia is practically free of scleroma.

\section{Asian Cases}

The number of case reports depends not only on thee frequency of the disease, but also on the standard of case recording and general public health statistics. ? Except for the presence of the disease in a given 0 country no valid conclusions can be drawn from the literature.

Two cases from Turkey and three from Iraq are $\frac{\mathbb{Q}}{\mathbb{Q}}$ recorded. Numerous cases were collected ing Kazakhistan, Uzbekistan, Turkmenistan, and 
Tadjikistan (Barilyak, 1962; Derepa, 1965). Barilyak confirmed the diagnosis with impression smears and nasal scrapings in $94 \%$ of 646 cases.

Many case reports have appeared since 1889 from the Indian subcontinent. Wahi and Misra (1964) collected 85 cases from the literature before 1941 and added 30 of their own. Another 50 cases have been reported since.

Common environmental and socioeconomic factors in some tribes and communities of Indonesia produce foci of endemic scleroma. A series of 53 families with numerous cases has been recorded (Oomen, 1938). The disease is also found in the Philippines, Japan, and China.

\section{Case Reports}

\section{CASE 1}

A 28-year-old woman from Fassa $(1,200 \mathrm{~m}$ above sea level) had been bitten by a donkey three years before admission. She complained of slowly progressing nasal obstruction and frequent epistaxes following the nasal trauma. On admission both nostrils were blocked by granulation tissue, which extended onto the upper lip. The nose was dilated and flattened in a typical fashion. Biopsy showed that the granulation tissue consisted of lymphocytes, plasma cells with Russell bodies, and characteristically distended histiocytes containing clumps of bacilli (Mikulicz cells). Bacteriological studies confirmed the presence of Klebsiella rhinoscleromatis. The patient received 2,000 r superficial radiotherapy and was seen six months later in an essentially unchanged condition.

\section{CASE 2}

A 30-year-old woman from Behbehan (altitude $800 \mathrm{~m}$ ) developed slowly progressive nasal obstruction in the course of a year. Her physician removed a 'polyp' which very soon recurred. On admission

\begin{tabular}{|c|c|c|c|c|}
\hline & $\begin{array}{l}\text { Kl. } \\
\text { Scleromatis }\end{array}$ & $\begin{array}{l}\text { Kl. } \\
\text { Ozaenae }\end{array}$ & $\begin{array}{l}\text { Kl. } \\
\text { Friedlaender }\end{array}$ & $\begin{array}{l}\text { Strain from } \\
\text { Case } 2\end{array}$ \\
\hline Capsule & + & + & + & + \\
\hline Motility & - & - & - & - \\
\hline $\begin{array}{l}\text { IMVIC reaction } \\
\text { Dextrose }\end{array}$ & - & + & - & - \\
\hline $\begin{array}{l}\text { Dextrose } \\
\text { Sucrose }\end{array}$ & & & & - \\
\hline $\begin{array}{l}\text { Sucrose } \\
\text { Gelatin }\end{array}$ & $(+)$ & $(+)$ & $\div$ or $(\div)$ & $\mathbf{A}$ \\
\hline $\begin{array}{l}\text { Gelatin } \\
\text { Oxidase test }\end{array}$ & + & - & + & $\overline{-}$ \\
\hline Lactose & - & - & & $\mathbf{A}$ \\
\hline $\begin{array}{l}\text { Maltose } \\
\text { Dulcitol }\end{array}$ & - & - & & $\mathbf{A}$ \\
\hline $\begin{array}{l}\text { Dulcitol } \\
\text { Rhamnose }\end{array}$ & - & - & & $\overline{\mathbf{A}}$ \\
\hline
\end{tabular}

Table Bacteriological studies in case $2^{1}$

Slightly sensitive to chloromycetin.

Resistant to kanamycin, tetracycline, streptomycin, gantrisin, neomycin, penbritin, and orbenin.
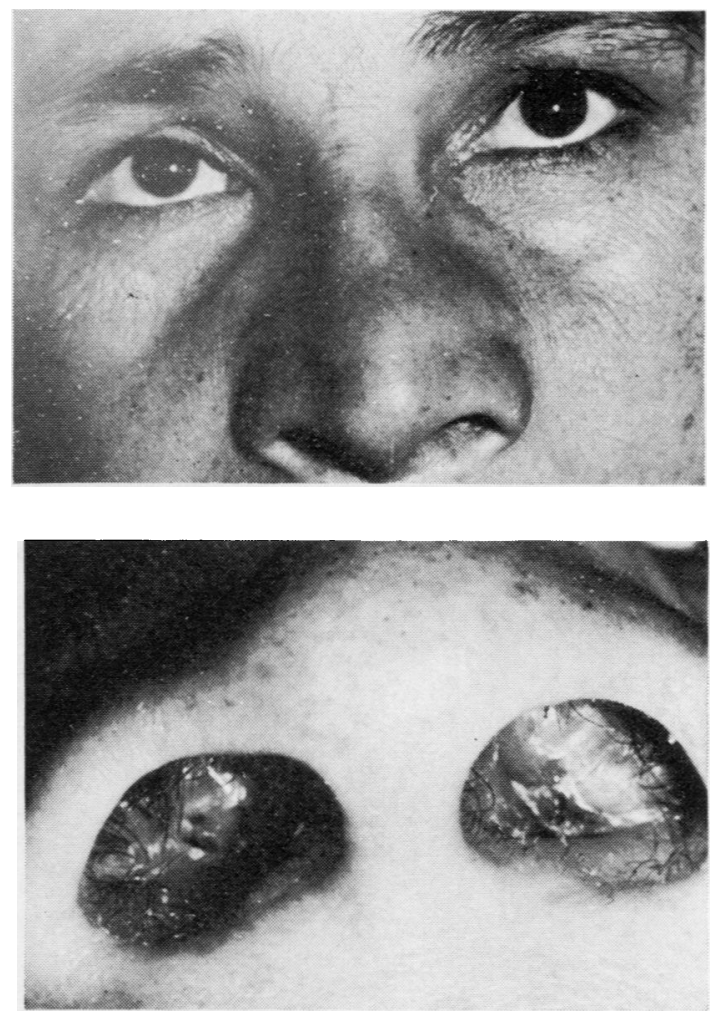

Fig. 1a and $\mathrm{b}$ Case 2: note the distended and enlarged turbinate through the dilated nostrils. The nasal canal is completely obstructed.

both nostrils were occluded by a soft mass of granulation tissue with a firm base in the gingivobuccal sulcus. The base was distended in the midline (Fig. 1). Microscopic examination showed the typical granulation tissue with Mikulicz cells. The patient received a full course of streptomycin after local resection of some of the granulation tissue to permit nasal drainage and easier breathing. The postoperative course was satisfactory.

\section{Discussion}

Scleroma is almost exclusively a disease of the respiratory passages, since their mucus supports the growth of the bacillus (Hoffman, 1968). Sixty per cent of all nasal scleromata have eventually laryngeal, $28 \%$ nasopharyngeal, $16 \%$ pharyngeal, and $9 \%$ tracheal and bronchial complications and involvement. The progressively expansive growth of the untreated granulation tissue may produce pressure atrophy and destruction of bone, occasionally 


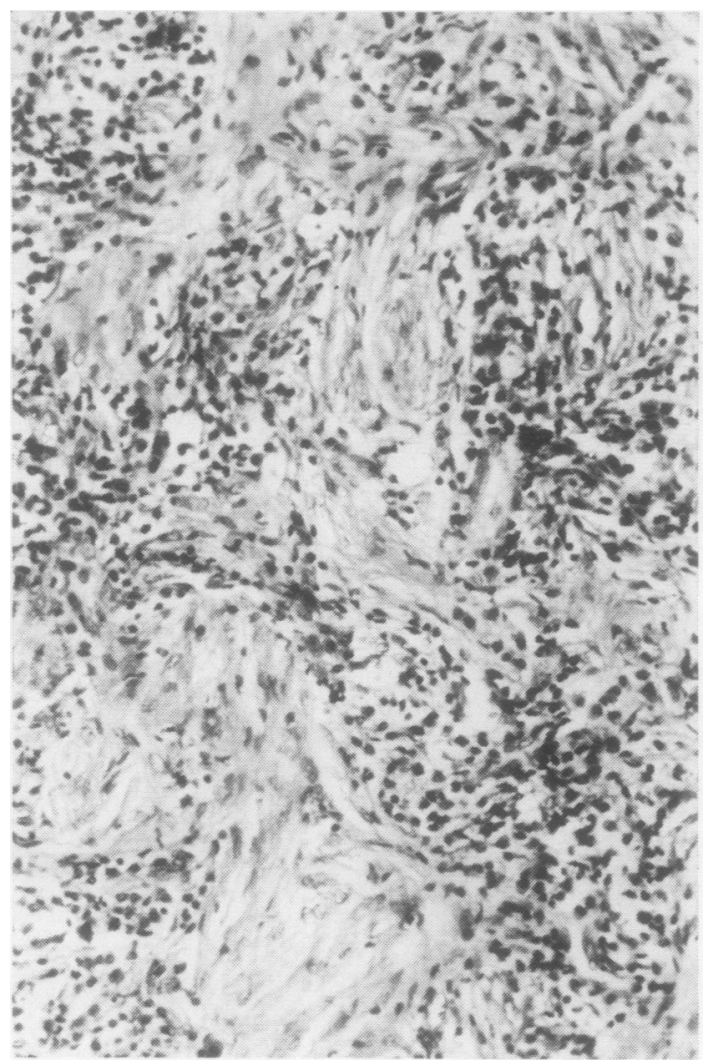

Fig. 2 Granulation tissue consisting of plasma cells and fibroblasts. The enlarged histiocytes with clear cytoplasm are prominent throughout the lesion (Mikulicz cells). $H$ and $E \cdot 120$.

extending into the orbit or reaching the meninges through the ethmoid or sphenoid bones. Involvement of the skin of the cheek, neck, forehead, and back has been reported. Nasal lesions may grow through the Eustachian tube into the antrum. Rare cases of the oesophagus, tonsils, bowel, and cervical lymph nodes are recorded.

Clinical diagnosis is usually not difficult. It should be confirmed by bacteriological determination of the Klebsiella, from nasal smears, needle aspiration of the lesion and cytological determination of Mikulicz cells, or by biopsy.

Streptomycin and aureomycin are the recommended therapeutic agents. Resistant strains have been described. Treatment must be prolonged, especially in all those cases in which reinfectio $\stackrel{0}{\vec{*}}$ from a carrier is to be expected (Shvartsberg. Kozitskaia, Derkach, and Zaitesva, 1952; Dursk 1957). Local resection before antibiotic therapy helpful, since the penetration of the therapeuti agent into the often large obstructive mass limited. Surgical treatment alone is not successful. $\widehat{\nabla}$

Peculiar historical and epidemiological parallef between leprosy and scleroma exist, although the tw 8 diseases are clinically dissimilar. Hansen's bacilluঙ was known for a long time and Koch's postulates. were only recently fulfilled. Infectivity of both organ isms is low. Close association with lepers foom prolonged periods of time is necessary for infection There is no explanation why some contacts contract the disease and others do not.

The bacilli of both diseases collect in specifie histiocytes, which permit pathological diagnosiso Virchow's leprosy cell with lepra globi in leproma tous leprosy and the Mikulicz's cell in scleromaz Both diseases require prolonged therapy, which haき become available only relatively recently.

The tissue affinity of Mycobacterium leprae and Klebsiella rhinoscleromatis differs specifically. $M \vec{\cdot}$ leprae infects primarily the ectoderm, including the neuroectoderm, and relatively late all other organs $B$. rhinoscleromatis grows only in association witlo nasal and respiratory mucus, which provide protection against host defence. Antibiotic therapø must therefore be prolonged to prevent interna $\overrightarrow{\vec{b}}$ reinfection.

\section{References}

Aldoin, F. (1957). Le sclérome en milieu marocain Bull. Acad naţ Med. (Paris), 141, 241-243.

Barilyak, R. A. (1962). The morphology and origin of Mikulicz cells (Russian), Arkh. Pat., 24 (6), 41-47.

Derepa, K. P. (1965). Electrophoretic study of the blood seruno proteins and lipoproteins in scleroma patients. (Russian Zh. ushn. nos. gorlov. Bolezn., 25 (4), 60-63.

Durska-Zakrzewska A. (1957). Le traitement spécifique du sclérome par la streptomycine. Rev. Laryng. (Bordeaux), 78, 360-419.

Frisch A. von. (1882). Zur Aetiologie des Rhinoskleroms. Wien. Mecto Wschr., 32, 969-972.

Hoffman, E. (1967). The etiology of rhinoscleroma. Int. Path., 8, 74-77

Hoffman, E., Correa, P., and Lujan, R. (1963). Immunofluorescencia: en el rinoescleroma. Rev. lat.-amer. Anat. pat., 7, 67-76.

Oomen, H. A. P. C., and Kirschner, L. (1938). Endemisch scleroom in een Minahassisch dorp. Geneesk. T. Ned.-Ind., 78, 1032-1057

Quevedo, J. (1949). Scleroma in Guatemala. Ann. Otol. (St. Louis) $\boldsymbol{\omega}$ $58,613-645$.

Shvartsberg, I. A.. Kozitskaia, K. P., Derkach, V. M.. and Zaitseva S. M. (1952). The treatment of rhinoscleroma with streptor mycin. (Russian) Vestn. Oto-rino-laring., 14 (2), 65-67.

Wahi, A. L., and Misra, R. N. (1964). A note on the geographica distribution of scleroma. J. Laryng., 78, 573-577. 